\title{
NOTES ON THE GENUS ZOSTERA S. LAT. IN NEW SOUTH WALES
}

\author{
S. W. L. JaCoBS AND A. Williams
}

(Accepted 19.6.1978)

\section{ABSTRACT}

Jacobs, S. W. L. and A. Williams (National Herbarium of New South Wales, Royal Botanic Gardens, Sydney, Australia 2000) 1980. Notes on the genus Zostera s. lat. in New South Wales. Telopea 1 (6): 451-455.-Zostera capricorni, Z. muelleri and Heterozostera tasmanica occur on the New South Wales coast. Their distribution is outlined, also their morphological and anatomical distinguishing characters are discussed. Lectotypes are designated and relevant citations included.

\section{INTRODUCTION}

Recent ecological studies sponsored by universities and government departments have produced numerous, non-fertile, eelgrass (Zostera s. lat.) specimens for identification. The paucity and poor quality of herbarium collections has made it difficult to identify these specimens. Collections of fertile material (although frequently present for up to six months of the year) or of rhizomes, the anatomical characters of which may be important for identification, are often missing both from "grab" samples and from drift material. Because of these factors, it was necessary to examine the anatomical characters of the rhizome mentioned by den Hartog (1970) and to relate these to anatomical features of the stem and leaf. Once this relationship was established, it was possible to use stem and leaf anatomy as an aid in the identification of incomplete collections.

The paucity of herbarium collections in the past has meant incomplete distributional information for species of eelgrass in New South Wales. Prior to the present study there were no specimens from a $650 \mathrm{~km}$ stretch of coastline (covering some $2 \frac{1}{2}$ degrees of latitude) in northeastern Victoria and southeastern New South Wales, and no information as to which species occurred there. The study has made it possible to provide up-to-date information on the distribution of each species.

\section{METHODS}

Relevant specimens in the National Herbaria of New South Wales (NSW) and Victoria (MEL) were studied, followed by the collection of material at as many localities as possible along the area of coastline which had not been sampled previously. Material for anatomical examination (preserved in $70 \%$ ethanol) was collected only from fertile specimens. Voucher specimens for all material are lodged at NSW. Material for sectioning was embedded in paraffin wax and sectioned on a rotary microtome.

\section{OBSERVATIONS AND TYPIFICATION}

\section{(A) Taxa present}

From examination of complete fertile specimens it was apparent that the two most common species of eelgrass in New South Wales are Zostera capricorni Aschers. and Z. muelleri Irmisch ex Aschers. Heterozostera tasmanica (Martens ex Aschers.) den Hartog, was found in only one locality. Full descriptions of these species with associated keys, discussion and illustrations are given by den Hartog (1970). 


\section{(B) Distinguishing characters}

\section{(i) Leaf-tip:}

One of the most useful characters, often seen in otherwise inadequate specimens, is the shape of the leaf-tip. The entire, truncate leaf-tip of $Z$. capricorni can be distinguished from the (deeply-) notched leaf-tips of $Z$. muelleri and Heterozostera tasmanica. Leaf-tip shape needs to be assessed as a population characteristic rather than on the basis of one or two individual leaf-tips, since events in the later stages of development of individual leaves of $Z$. muelleri and $H$. tasmanica may prevent the formation of a notch (Taylor, pers. comm.).

(ii) Vascular bundle distribution:

Z. muelleri (and other Zostera spp.) have one central bundle and two cortical vascular bundles in the rhizome internodes, while $H$. tasmanica has one central and four or more cortical bundles (den Hartog 1970). In H. tasmanica the cortical bundles tend to be grouped towards the two opposite sides of the rhizome rather than being spaced evenly. A similar criterion can be used in stems, even when only a short piece is available because in Zostera spp. the same number (2) of cortical bundles occurs in erect stems as in the rhizome, whereas in $H$. tasmanica the erect stems have more than two bundles (sometimes slightly fewer than in the attached rhizome).

(iii) Fibre bundle distribution:

The fibre bundles in $H$. tasmanica occur in both the inner and outer cortex of the rhizome, while in $Z$. muelleri and $Z$. capricorni they are restricted to the outer cortex.

No difference could be detected in the distribution of fibre bundles in several specimens of both $Z$. muelleri and Z. capricorni and in two specimens of the northern hemisphere species $Z$. marina $L$. This finding is contrary to the primary keycharacter employed by den Hartog (1970) who uses the distribution of fibre bundles in the rhizome as one difference between the subgenera Zostera (includes Z. marina) and Zosterella (includes $Z$. muelleri and $Z$. capricorni). This discrepancy should not affect the status of the subgenera which are still distinguished by the closed leaf sheath in subg. Zostera and the open sheath in subg. Zosterella.

The fibre bundles of the rhizome and stem as well as the "accessory" bundles in the leaf (sensu den Hartog 1970) are indistinguishable in their anatomy. Setchell (1933) indicates the similarity of these bundles in his description. It is likely that they both perform similar functions and possibly combine both the functions of vascular transport and mechanical support implied in the terminology. It is suggested that the term "fibre bundles" be used for the bundles in all three organs.

\section{(iv) Schizogenous air spaces:}

The schizogenous air spaces of the leaves in $H$. tasmanica are separated by singlelayered (occasionally two-layered) longitudinal diaphragms (1-2 cells thick in transection). $Z$. muelleri and $Z$. capricorni usually have the air spaces separated laterally by multi-layered longitudinal diaphragms. Single- or two-layered diaphragms are found only in very depauperate specimens.

(v) Cell membranes:

Raison (pers. comm.) in a joint study yet to be prepared for publication, has found that the cell membranes from samples of $Z$. capricorni and $Z$. muelleri behave quite differently when examined for temperature-induced phase changes using 
electron spin resonance. $Z$. muelleri membranes are characteristic of a chillingresistant species, whereas the membranes of $Z$. capricorni are more characteristic of a tropical or sub-tropical species. Samples were taken from the overlap zone of the two species distributions. No information is available about Heterozostera.

\section{(vi) Production of erect stems:}

H. tasmanica normally produces both flowering and non-flowering erect stems each spring and both types remain on the plant till the following autumn. In more marginal habitats, however, erect stems may not be produced each year. $Z$. muelleri and $Z$. capricorni normally only produce flowering erect stems. In cases where substrate has been washed away exposing more of the short vertical stems of Zostera. it may be possible to confuse the two genera by relying on this character.

The fruiting stems of $Z$. muelleri and the erect stems of $H$. tasmanica break off and drift, usually during autumn. After this occurs, it is virtually impossible to distinguish the two species from external morphological features.

(vii) Retinaculum shape:

The retinacula in $H$. tasmanica are linear-lanceolate, whereas those of $Z$. muelleri and $Z$. capricorni are obliquely ovate or triangular (den Hartog 1970).

\section{(C) Distribution of taxa}

Zostera capricorni occurs all along the New South Wales coast. It extends northwards into Queensland and southwards into Victoria, as far as Mallacoota $\left(37^{\circ} 33^{\prime} \mathrm{S}, 149^{\circ} 45^{\prime} \mathrm{E}\right)$, being less abundant south of $35^{\circ} \mathrm{S}$ latitude. The only record from Kangaroo Island (South Australia) is almost certainly drift material. The species also occurs on the coast of Lord Howe Island. It is found below high tide level in estuaries and bays which are at least periodically open to the sea. Healthy specimens are normally found growing in mud or in a mixture of mud and sand, occasionally overlying a substrate of rocks or sand. Specimens from sandy areas and/or on banks frequently exposed for long periods are characteristically small and narrow-leaved.

Zostera muelleri occurs at least as far north as Sussex Inlet $\left(35^{\circ} 09^{\prime} \mathrm{S}, 150^{\circ} 35^{\circ} \mathrm{E}\right)$ on the South Coast of New South Wales, and south and west into Victoria, Tasmania and South Australia. In New South Wales it is quite common in inlets and estuaries with restricted access to the sea and may occur in lagoons which are infrequently open to the sea. Although its habitat is otherwise similar to that of $Z$. capricorni, it is uncommon to find the two species growing together. In the single locality where this was observed, at Narooma, N.S.W., Z. muelleri was growing well and flowering alongside stunted and non-flowering $Z$. capricorni.

The only living occurrence of Heterozostera tasmanica in New South Wales is in Jervis Bay on the South Coast. It is found elsewhere along the southern coastline of Australia. It has not been recorded between Corner Inlet $\left(38^{\circ} 46^{\prime} \mathrm{S}, 146^{\circ} 19^{\prime} \mathrm{E}\right)$ in Victoria and Jervis Bay $\left(35^{\circ} 03^{\prime} \mathrm{S}, 150^{\circ} 44^{\prime} \mathrm{E}\right)$, despite sampling in this region during the present study. This apparently disjunct distribution is possibly explained by the tendency for this species to inhabit more exposed areas on sandier bottoms in its localities north-east along the coast from Melbourne than in its localities around Melbourne. Perhaps the only suitable locality between the two cited above would be in Twofold Bay $\left(37^{\circ} 05^{\prime} \mathrm{S}, 149^{\circ} 54^{\prime} \mathrm{E}\right)$, where it may yet be found. The three records from the Sydney region (den Hartog 1970) are drift specimens; the specimen from Pittwater resembles the broader-leaved Tasmanian material. 


\section{(D) Type citations and lectotypifications}

There has been some confusion over the citation of the type descriptions for these species and the designation of types and/or selection of lectotypes. The correct citations are given here with relevant notes and lectotypes are chosen for each of the three species.

Heterozostera tasmanica (Martens ex Aschers.) C. den Hartog, Sea-Grasses of the World, 116 (1970). BASronYM: Zostera tasmanica Martens ex Aschers., Linnaea 35: 168 (1867).

Lecrotype (here designated): Port Phillip, Victoria, F. Mueller 1866 (MEL 2905). This is the only specimen in MEL collected prior to the description. It was seen by Ascherson. Ascherson's other duplicates were in Berlin and were apparently destroyed. This specimen has usually been regarded as the type.

Zostera capricorni Aschers., Sitzungsber. Ges. Naturf. Freunde Berlin 1876: 11 (1877?)*; also Verh. Bot. Vereins Prov. Brandenberg 18: 59 (1876) (1877?)*.

LectotyPe (here designated): Moreton Bay, Naumann 10.x.1875 (UC).

Because of the uncertainty as to which of these two references should be accepted as the correct citation for $Z$. capricorni Aschers., we have formally selected a lectotype, even though we have not seen the specimen. Naumann's specimen from Moreton Bay (10.x.1875) (UC) has usually been regarded as the type and is mentioned in both descriptions. It has been examined by den Hartog who treats it as the type (den Hartog 1970) without stating it as such formally.

Zostera muelleri Irmisch ex Aschers., Linnaea 35: 168 (1867).

LeCtotype (here designated): Australia felix, F. Mueller Nov. 1852 (MEL 3759).

(E) Relationships between Zostera and Heterozostera

Differences in normal growth behaviour and anatomy are the characters den Hartog used to separate Heterozostera from Zostera at the generic level.

We agree with den Hartog (1970) in regarding Heterozostera as morphologically more primitive than Zostera and would add that the leaf anatomy in Heterozostera, with its less complex longitudinal diaphragms, would also tend to support this.

In marginal conditions (e.g. some areas in Jervis Bay) Heterozostera may only spasmodically produce erect stems, instead of its normal annual production of both erect vegetative and floral stems. This approachs the growth behaviour of Zostera. It is tempting to hypothesize that such a modified growth pattern in Heterozostera is similar to the growth pattern that could be expected in the progenitors of Zostera.

We emphasize that our recognition here of the genus Heterozostera is consistent with current usage only and its taxonomic status may require further consideration.

* There is some doubt about the actual date of publication in both of these cases. There is evidence that the latter was probably published in 1877 but only circumstantial evidence about the former. They are cited here in the same order as by den Hartog. 


\section{REFERENCES}

Hartog, C. den, (1970)-The sea-grasses of the world. North Holland Publishing Co., Amsterdam.

Setchell, W. A., (1933)-A preliminary survey of the species of Zostera L. Proc. Natl. Acad. Sci. Wash. 19: 810-817.

\section{APPENDIX}

Specimens examined in anatomical studies. All specimens are located in NSW. Zostera marina: Eculescu NSW 66663; Borza NSW 66667.

Zostera capricorni: Williams 135; Jacobs 2429, 2444, 2452.

Zostera muelleri: Jacobs 2360, 2362, 2370, 2372, 2374, 2383, 2390, 2398, 2400, 2401, 2402, 2406, $2407,2437,2438$.

Heterozostera tasmanica: Jacobs 2364, 2367, 2369, 2375, 2384, 2388, 2389, 2391, 2455; May NSW 122567, NSW 122571, NSW 122573; Rodway 9192; State Fisheries NSW 122568, NSW 122569, NSW 122570, NSW 122572, NSW 122574; Thompson NSW 44444; Thorne 26548 . 